ISSN (Print) : 1412-7601

ISSN (Online) : 2654-8712

Volume 6, No.1 Maret 2020

EKONOBIS

http://www.ekonobis.unram.ac.id

\title{
Analisis Diskriminan Kunjungan Wisatawan Ke Tempat Wisata Sebelum Dan Setelah Gempa Bumi Di Kabupaten Lombok Utara (KLU)
}

\section{M.Mujahid Dakwah, Himawan Sutanto.}

Universitas Mataram

\section{ARTICLE INFO}

Keywords :

Discriminant Analysis,

Tourist, Tourist Attraction,

North Lombok District

ABSTRACT : The purpose of this study is (a) To analyze what factors distinguish between foreign tourists and the archipelago in visiting tourist attractions in North Lombok Regency (KLU) before and after the earthquake (b) To find out how discriminant models can be formed from foreign tourist visits and the archipelago to tourist attractions in North Lombok Regency (KLU) before and after the earthquake. The data used in this study are secondary data from the KLU Tourism Office, the Central Statistics Agency (BPS) NTB, Bank Indonesia. analysis of the data used in this study is the Discriminant Analysis using SPSS software.17. The results of the study show that the rupiah exchange rate variable, NTB GRDP, KLU GRDP which distinguishes foreign tourists and the archipelago in visiting tourist attractions in North Lombok Regency before and after the earthquake earth.

Kata Kunci :

Analisis Diskriminan, Wisatawan, Tempat Wisata, Kabupaten Lombok Utara

\section{ABSTRAK: Tujuan penelitian ini adalah (a) Untuk menganalisis faktor apakah yang} membedakan wisatawan asing dan nusantara dalam melakukan kunjungan ke Tempat Wisata di Kabupaten Lombok Utara (KLU)sebelum dan setelah gempa bumi (b) Untuk mengetahui bagaimana model diskriminan yang dapat dibentuk dari kunjungan wisatawan asing dan nusantara ke Tempat Wisata di Kabupaten Lombok Utara (KLU) sebelum dan setelah gempa bumi. Data yang digunakan dalam penelitian ini adalah data sekunder yang berasal dari Dinas Pariwisata KLU, Badan Pusat Statistik (BPS) NTB, Bank Indonesia.Variabel Penelitian yang digunakan adalah Tingkat Inflasi NTB, Tingkat Inflasi KLU, Kurs rupiah, PDRB NTB, PDRB KLU.Teknik analisis data yang digunakan dalam penelitian ini adalah Analisis Diskriminan dengan menggunakan software SPSS.17. Hasil Penelitian menunjukkan bahwa variable Kurs rupiah, PDRB NTB, PDRB $K L U$ yang membedakan wisatawan asing dan nusantara dalam melakukan kunjungan ke Tempat Wisata di Kabupaten Lombok Utara sebelum dan setelah gempa bumi.

Corresponding Author:

Alamat : Program Studi Ekonomi Pembangunan, Fakultas Ekonomi dan Bisnis, Universitas Mataram, Jln. Majapahit No. 62 Mataram.

e-mail: mujahid@unram.ac.id 


\section{PENDAHULUAN}

\section{Latar Belakang}

Pengembangan sektor pariwisata dilakukan juga oleh Pemerintah kabupaten Lombok utara (KLU) yang menjadikan pariwisata sebagai sektor unggulan karena potensi wisata yang dimiliki oleh kabupaten Lombok utara cukup banyak dan memiliki potensi yang cukup banyak yang terlihat dari potensi pariwisata yang dimiliki oleh kabupaten Lombok utara, terutama wisata pantai yang cukup terkenal dikalangan wisatawan seperti tiga gili yang memiliki wisata pantai yang indah yaitu gili tramena (Trawangan, Meno, Air) yang terletak dikecamatan Pemenang, yang dapat menarik banyak minat wisatawan baik wisatawan asing maupun wisatawan nusantara. Potensi wisata yang cukup besar tersebut akan mendatangkan manfaat ekonomi bagi pemerintah maupun masyarakat sekitar terutama masyarakat KLU. Agar dapat tempat wisata di kawasan Lombok utara mendatangkan manfaat ekonomi bagi masyarakat dan pemerintah daerah maka perlu adanya perhatian dari PEMDA KLU dengan mengeluarkan kebijakan dan program dalam mengembangkan berbagai potensi pariwisata di kabupaten Lombok utara yang menjadi indikator keberhasilan pariwisata.

Selain itu juga kunjungan wisatawan asing dan nusantara sebelum gempa bumi di kabupaten Lombok utara cukup tinggi yang terlihat pada tabel 1

Grafik 1 Jumlah kunjungan wisatawan di Kabupaten Lombok Utara (KLU) tahun 2012-2017

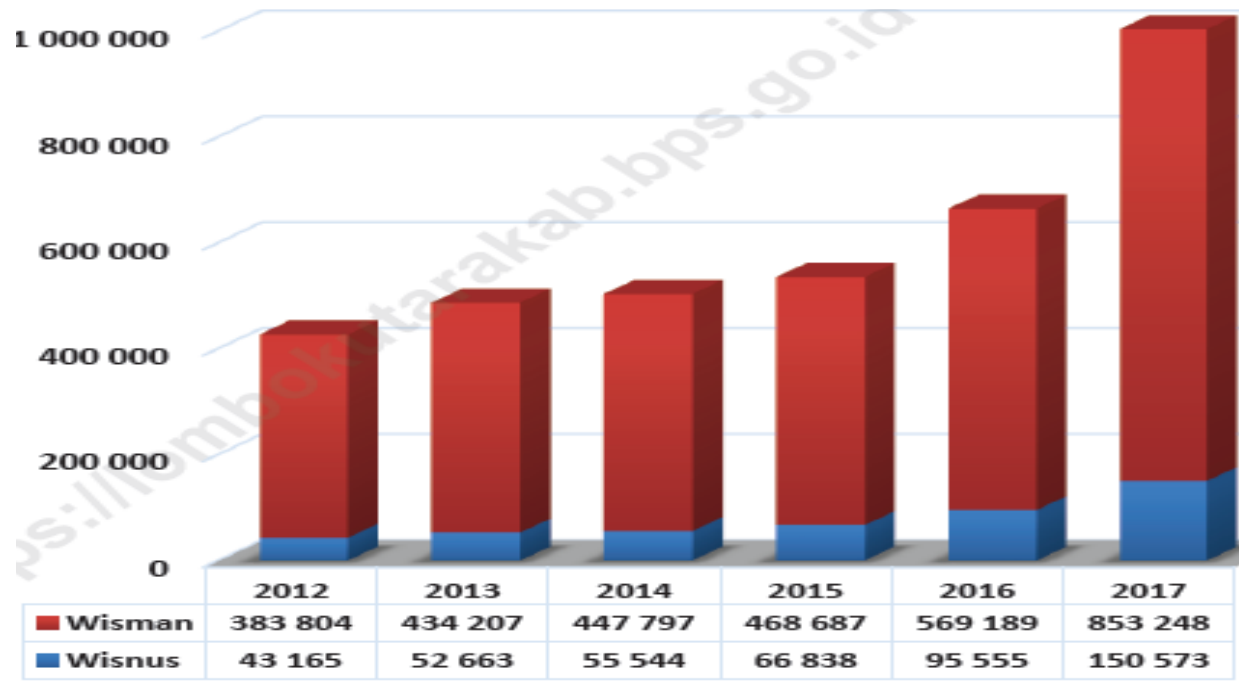

Sumber : KLU dalam Angka 2018 (Diolah) 
Berdasarkan tabel 1.1 diatas terlihat bahwa jumlah kunjungan wisatawan di kabupaten Lombok utara mengalami kenaikan dimana pada tahun 2012 jumlah wisatawan mancanegara sebesar 383.804 orangdan wisatawan nusantara berjumlah 43.165 orang sedangkan pada tahun 2017 jumlah wisatawan mancanegara sebesar 853.248 orangdan wisatawan nusantara berjumlah 150.573 orang, artinya kabupaten Lombok utara memiliki tempat wisata yang disukai oleh wisatawan mancanegara maupun wisatawan nusantara terutama wisata pantai yang berada di tiga gili di kabupaten Lombok utara.

Adanya gempa bumi yang menimpa pulau lombok khususnya Kabupaten Lombok Utara (KLU) pada bulan Agustus 2018 lalu memberikan dampak yang cukup besar terutama dampak bagi sector pariwisata dimana banyak daerah wisata yang mendapatkan dampak langsung seperti banyaknya hotel dan infrastruktur pariwisata lainnya yang mengalami kerusakan akibat gempa bumi yang melanda pulau Lombok dan kabupaten Lombok utara sehingga tentunya akan berpengaruh langsung terhadap sector pariwisata. Pengaruh langsung dari sector pariwisata akibat gempa bumi di kabupaten Lombok utara (KLU) adalah jumlah kunjungan wisatawan yang berkunjung ke tempat wisata dikabupaten Lombok utara (KLU) baik wisatawan mancanegara maupun wisatawan nusantara, oleh karena itu diperlukan kebijakan dari pemerintah kabupaten Lombok utara (KLU) terutama dari dinas pariwisata kabupaten Lombok utara (KLU) untuk bangkit kembali dan menarik minat wisatawan untuk berkunjung kekabupaten Lombok utara (KLU), oleh karena itu diperlukan identifikasi variablevariabel yang membedakan kunjungan antara wisatawan nusantara dengan wisatawan mancanegara agar dapat disiapkan berbagai fasilitas program atau berbagai kebijakan yang mendukung wisatawan untuk berkunjung ke tempat wisata di kabupaten Lombok utara (KLU) pasca gempa bumi yang menimpa kabupaten Lombok utara (KLU), Sehingga diperlukan penelitian yang berjudul "'Analisis Diskriminan Kunjungan Wisatawan Ke Tempat Wisata Sebelum Dan Setelah Gempa Bumi Di Kabupaten Lombok Utara (KLU).

\section{Perumusan Masalah}

Dari uraian di atas dapat diambil pokok permasalahannya yaitu:

1. Apakah variable-variabel yang membedakan wisatawan dalam melakukan kunjungan ke tempat 
wisata sebelum dan setelah gempa bumidi Kabupaten Lombok Utara (KLU).

2. Bagaimana model diskriminan yang dapat dibentuk dari kunjungan ke tempat wisata sebelum dan setelah gempa bumi di Kabupaten Lombok Utara (KLU).

\section{Tujuan Penelitian}

Adapun Tujuan penelitian:

1. Untuk menganalisis variablevariabel yang membedakan wisatawan asing dan nusantara dalam melakukan kunjungan ke tempat wisata sebelum dan setelah gempa bumidi Kabupaten Lombok Utara (KLU).

2. Untuk mengetahui bagaimana model diskriminan yang dapat dibentuk dari variable-variabel yang membedakan wisatawan asing dan nusantara dalam melakukan kunjungan ke tempat wisata sebelum dan setelah gempa bumi di Kabupaten Lombok Utara (KLU).

\section{Manfaat penelitian ini adalah:}

\section{Adapun manfaat penelitian adalah :}

1. Bermanfaat bagidinas pariwisata kabupaten lombok utara dalam meningkatkan kunjungan ke tempat wisata di kabupaten lombok utara pasca gempa bumi dikabupaten Lombok utara dengan manajemen kepariwisataan.

2. Bermanfaat bagi pemerintah kabupaten Lombok utara dalam mengembangkan objek wisata di kabupaten Lombok utara pasca gempa bumi untuk dapat menarik wisatawan kembali ke objek wisata di KLU

3. Secara teoritis sebagai tambahan refrensi bagi pihak-pihak yang ingin melakukan penelitian lebih lanjut berkaitan denganAnalisis Diskriminan Kunjungan Wisatawan Ke Tempat Wisata Sebelum Dan Setelah Gempa Bumi Di Kabupaten Lombok Utara (KLU).

\section{TINJAUAN PUSTAKA}

\section{Penelitian Terdahulu}

Sharifi \& Gilaninia (2013) meneliti tentang faktor-faktor ekonomi yang mempengaruhi penawaran pariwisata di Iran dengan judul "Economic Factors Affecting Tourism Supply", tujuan penelitiannya adalah untuk mengetahui pengaruh faktor-faktor ekonomi terhadap penawaran pariwisata di Iran.Data yang digunakan dalam penelitian ini adalah data sekunder seperti nilai tukar (kurs) dan pendapatan perkapita masyarakat 
selama tahun pengamatan 2007-2011, teknik analisis data yang digunakan adalah analisis regresi linier logaritma. Hasil penelitiaannya menunjukkan bahwa hubungan yang signifikanantara pendapatan per kapita rumah tangga perkotaan dan jumlah penawaran pariwisata di Iran dan jugaada hubungan yang signifikan antara nilai tukar dengan jumlah penawaran pariwisata di Iran dengan Pendapatan perkapita memilikifaktor yang paling penting dalam mempengaruhi penawaran pariwisata di Iran.

Ibrahim (2011) meneliti faktorfaktor yang menentukan permintaan wisatawan internasional di Mesirdengan judul penelitian "The Determinants of International Tourism Demand for Egypt: Panel Data Evidence " .Tujuandari penelitian ini adalah untuk mengetahui faktor-faktor penentu utama dari wisatawan internasional di Mesir. Variabel yang digunakan dlam penelitian ini adalah jumlah kunjungan wisatawan asing sebagai variabel dependen (terikat) sedangkan variabel independennya (bebas) yang digunakan dalam penelitian ini adalah produk nusantara bruto (PDB), Tingkat harga, pasar bebas, Nilai tukar. Data yang digunakan dalam penelitian ini adalah data panel (poling) dengan periode pengamatan dati tahun 1990 sampai dengan 2008. Teknik analisis data yang digunakan adalah analisis regresi Log linier berganda. Hasil penelitian menunjukkan PDB memiliki pengaruh yang signifikan positif, nilai tukar dan tingkat harga memiliki pengaruh yang signifikan negative terhadap jumlah kunjungan wisatawan asing di Mesir.

Emilia Gabroveanu et.al, (2010) melakukan penelitian yang berjudul "Analysis of Main Economic Factors Influence on Romanian Tourists Number Accommodated in Romania, using Anova Method". Tujuan penelitiannya adalah untuk mengidentifikasi pengaruh faktor ekonomi utama seperti total pendapatan rumah tangga dan indeks harga konsumen terhadap jumlah wisatawan di Rumania pada periode 2001-2007. Variabel penelitian yang digunakan adalah jumlah kunjungan wisatawan sebagai variabel dependen/terikat $(\mathrm{Y})$, sedangkan variabel independen/bebas $(X)$ yang digunakan dalam penelitian adalah pendapatan rumah tangga dan indek harga konsumen. Metode penelitian yang digunakan adalah metode multifactorial regression model dan variation analysis(ANOVA). Hasil penelitian menunjukkan bahwa jumlah wisatawan yang berkunjung ke Rumania dantotal pendapatan rumah tangga, dan 
indek harga konsumenMemiliki hubungan yang sangat kuat dengan korelasi memiliki nilai 0,974653.Persentase pengaruh total pendapatanrumah tangga dan indeks harga konsumen,tercermin dari nilai $R$ Square sebesar 94.99\%, dimana sisanya $5,01 \%$ dipengaruhi oleh faktor lainnya.Harga (IHK) yang lebih rendah menyebabkan peningkatanpermintaan pariwisata (peningkatan jumlah wisatawan,lama tinggal, frekuensi perjalanan semakin banyak), dan begitupun sebaliknya.

Tse (2001) melakukan penelitian yang berjudul "Estimating the impact of economic factors on tourism: evidence from Hong Kong", penelitian ini ingin melihat pengaruh faktor-faktor ekonomi terhadap pengeluaran wisatawan dan tingkat hunian kamar hotel studi kasus di Hongkong. Variabel penelitian yang digunakan dalam penelitian ini adalah pengeluaran wisatawan, tingkat hunian hotel sebagai variabel terikat (dependen) dan expected income, expected exchange rate and price level sebagai variabel bebas (independen). Teknik analisis data yang digunakan adalah model persamaan linier.Hasil penelitiannya menunjukkan bahwa pengeluaran pariwisata dipengaruhi oleh pendapatan yang diharapkan, nilai tukar yang diharapkan dan tingkat harga (inflasi).Selain itu juga Tingkat hunian hotel dipengaruhi oleh variabel nilai tukar, tingkat harga, tingkat hunian dan lama tinggal wisatawan di Hongkong.

I Nengah Wijaya (2011) melakukan penelitian yang berjudul " Pengaruh Jumlah Wisatawan Mancanagera, Lama Tinggal, Dan Kurs Dollar Amerika Terhadap Penerimaan Produk Nusantara Regional Bruto Industry Pariwisata Kabupaten Badung Tahun 1997-2010" Tujuan penelitiannya adalah untuk mengetahui pengaruh jumlah wisatawan mancanagera ,lama tinggal, dan kurs dollar Amerika terhadap penerimaan produk nusantara regional bruto industry pariwisata Kabupaten Badung tahun 1997-2010, variabel penelitian yang digunakan adalah jumlah wisatawan mancanagera, lama tinggal, kurs dollar Amerika dan variabel PDRB kabupaten Badung, data penelitian yang digunakan adalah data sekunder berupa data jumlah wisatawan mancanagera, lama tinggal, kurs dollar Amerika dan variabel PDRB selama periode 1997-2010 sedangkan data teknik analisis yang digunakan adalah analisis regresi berganda dengan bantuan software SPSS. Hasil penelitiannya menunjukkan bahwa secara parsial jumlah 
wisatawanmanca negara, dan kurs dolar Amerika berpengaruh nyata dan positif terhadappenerimaan Produk Nusantara Regional Bruto industri pariwisata KabupatenBadung, sedangkan lama tinggal berpengaruh tidak nyata terhadap penerimaanProduk Nusantara Regional Bruto industri pariwisata Kabupaten Badung.Secara simultan jumlah wisatawan mancanegara, lama tinggal, dan kursdolar Amerika berpengaruh nyata terhdap penerimaan Produk Nusantara RegionalBruto industri pariwisata Kabupaten Badung dengan nilai R2 dan R masing-masingsebesar 0,706 , dan 0,840 dengan jumlah wisatawan mancanegara sebagai faktoryang paling besar pengaruhnya terhadap penerimaan Produk Domesti RegionalBruto pariwisata Kabupaten Badung dengan nilai koefisien determinasi parsial $\left(\mathrm{R}^{2}\right)$ atau zero order sebesar 0,506 atau $25,60 \%$.

Eka Armoni (2011) melakukan penelitian yang berjudul "Pengaruh
Pendapatan Per Kapita, Nilai Tukar, Dan Keamanan Terhadap Jumlah Kunjungan Wisatawan Korea Selatan Ke Bali". Tujuan penelitiannya adalah untuk mengetahui Pengaruh/hubungan antara Pendapatan Per Kapita, Nilai Tukar, Dan Keamanan Terhadap Jumlah Kunjungan Wisatawan Korea Selatan Ke Bali. Variabel penelitian yang digunakan adalah Pendapatan Per Kapita, Nilai Tukar dan Keamanan sebagai variabel Independen/bebas (X) sedangkan variabel dependenya/terikatnya (Y) menggunakan variabel Jumlah Kunjungan Wisatawan. Alat alnalisis yang digunakan adalah Regresi Linier Berganda (OLS). Hasil penelitiannya menunjukkan variabel pendapatan perkapita (income percapita) dan nilai tukar berpengaruh signifikan terhadap jumlah kunjungan wisatawan korea ke bali sedangkan variabel keamanan tidak berpengaruh terhadap terhadap jumlah kunjungan wisatawan korea ke bali.

Tabel 1 Rangkuman penelitian terdahulu

\begin{tabular}{|c|c|c|c|c|}
\hline $\begin{array}{l}\text { Penulis } \\
\& \text { tahun }\end{array}$ & Judul & $\begin{array}{c}\text { Tujuan } \\
\text { penelitian }\end{array}$ & $\begin{array}{c}\text { Metode } \\
\text { Penelitia } \\
n\end{array}$ & Kesimpulan \\
\hline $\begin{array}{l}\text { Sharifi \& } \\
\text { Gilaninia } \\
(2013)\end{array}$ & $\begin{array}{l}\text { Economic } \\
\text { Factors } \\
\text { Affecting } \\
\text { Tourism } \\
\text { Supply }\end{array}$ & $\begin{array}{l}\text { untuk } \\
\text { mengetahui } \\
\text { pengaruh faktor- } \\
\text { faktor ekonomi } \\
\text { terhadap } \\
\text { penawaran } \\
\text { pariwisata di Iran }\end{array}$ & $\begin{array}{l}\text { Regresi } \\
\text { log linier } \\
\text { berganda }\end{array}$ & $\begin{array}{l}\text { Terdapat hubungan yang } \\
\text { signifikan antara pendapatan per } \\
\text { kapita rumah tangga perkotaan } \\
\text { dan jumlah penawaran pariwisata } \\
\text { di Iran dan juga ada hubungan } \\
\text { yang signifikan antara nilai tukar } \\
\text { dengan jumlah penawaran } \\
\text { pariwisata di Iran dengan } \\
\text { Pendapatan perkapita memiliki }\end{array}$ \\
\hline
\end{tabular}




\begin{tabular}{|c|c|c|c|c|}
\hline & & & & $\begin{array}{l}\text { faktor yang paling penting dalam } \\
\text { mempengaruhi penawaran } \\
\text { pariwisata di Iran. }\end{array}$ \\
\hline $\begin{array}{l}\text { Ibrahim } \\
\text { (2011) }\end{array}$ & $\begin{array}{l}\text { The } \\
\text { Determinants } \\
\text { of } \\
\text { International } \\
\text { Tourism } \\
\text { Demand for } \\
\text { Egypt: Panel } \\
\text { Data Evidence }\end{array}$ & $\begin{array}{l}\text { untuk } \\
\text { mengetahui } \\
\text { faktor-faktor } \\
\text { penentu utama } \\
\text { dari wisatawan } \\
\text { internasional di } \\
\text { Mesir }\end{array}$ & $\begin{array}{l}\text { Regresi } \\
\text { log linier } \\
\text { berganda }\end{array}$ & $\begin{array}{l}\text { PDB memiliki pengaruh yang } \\
\text { signifikan positif, nilai tukar dan } \\
\text { tingkat harga memiliki pengaruh } \\
\text { yang signifikan negative terhadap } \\
\text { jumlah kunjungan wisatawan } \\
\text { asing di Mesir. }\end{array}$ \\
\hline $\begin{array}{l}\text { Gabrove } \\
\text { anu,et.al, } \\
(2010)\end{array}$ & $\begin{array}{l}\text { Analysis of } \\
\text { Main } \\
\text { Economic } \\
\text { Factors } \\
\text { Influence on } \\
\text { Romanian } \\
\text { Tourists } \\
\text { Number } \\
\text { Accommodate } \\
\text { d in Romania, } \\
\text { using Anova } \\
\text { Method }\end{array}$ & $\begin{array}{l}\text { untuk } \\
\text { mengidentifikasi } \\
\text { pengaruh faktor } \\
\text { ekonomi utama } \\
\text { seperti total } \\
\text { pendapatan } \\
\text { rumah tangga } \\
\text { dan indeks harga } \\
\text { konsumen } \\
\text { terhadap jumlah } \\
\text { wisatawan di } \\
\text { Rumania pada } \\
\text { periode 2001- } \\
2007\end{array}$ & $\begin{array}{l}\text { Analisis } \\
\text { regresi } \\
\text { linier } \\
\text { berganda } \\
\& \\
\text { ANOVA }\end{array}$ & $\begin{array}{l}\text { jumlah wisatawan yang } \\
\text { berkunjung ke Rumania dan total } \\
\text { pendapatan rumah tangga, dan } \\
\text { indek harga konsumen Memiliki } \\
\text { hubungan yang sangat kuat } \\
\text { dengan korelasi memiliki nilai } \\
\text { 0,974653. Dimana IHK memiliki } \\
\text { hubungan yang paling kuat } \\
\text { sehingga Harga (IHK) yang lebih } \\
\text { rendah menyebabkanpeningkatan } \\
\text { permintaan pariwisata } \\
\text { (peningkatan jumlah wisatawan, } \\
\text { lama tinggal, frekuensi perjalanan } \\
\text { semakin banyak), dan begitupun } \\
\text { sebaliknya. }\end{array}$ \\
\hline $\begin{array}{l}\text { Tse } \\
\text { (2001) }\end{array}$ & $\begin{array}{l}\text { Estimating the } \\
\text { impact of } \\
\text { economic } \\
\text { factors on } \\
\text { tourism: } \\
\text { evidence from } \\
\text { Hong Kong }\end{array}$ & $\begin{array}{l}\text { Untuk } \\
\text { mengetahui } \\
\text { pengaruh faktor- } \\
\text { faktor ekonomi } \\
\text { terhadap } \\
\text { pengeluaran } \\
\text { wisatawan dan } \\
\text { tingkat hunian } \\
\text { kamar hotel studi } \\
\text { kasus di } \\
\text { Hongkong. }\end{array}$ & $\begin{array}{l}\text { Regresi } \\
\text { linier } \\
\text { berganda }\end{array}$ & $\begin{array}{l}\text { pengeluaran pariwisata } \\
\text { dipengaruhi oleh pendapatan } \\
\text { yang diharapkan, nilai tukar yang } \\
\text { diharapkan dan tingkat harga } \\
\text { (inflasi). Selain itu juga Tingkat } \\
\text { hunian hotel dipengaruhi oleh } \\
\text { variabel nilai tukar, tingkat harga, } \\
\text { tingkat hunian dan lama tinggal } \\
\text { wisatawan di Hongkong. }\end{array}$ \\
\hline $\begin{array}{l}\text { I Nengah } \\
\text { Wijaya } \\
(2011)\end{array}$ & $\begin{array}{l}\text { Pengaruh } \\
\text { Jumlah } \\
\text { Wisatawan } \\
\text { Mancanagera, } \\
\text { Lama Tinggal, } \\
\text { Dan Kurs } \\
\text { Dollar } \\
\text { Amerika } \\
\text { Terhadap } \\
\text { Penerimaan } \\
\text { PDRB Industry } \\
\text { Pariwisata } \\
\text { Kabupaten }\end{array}$ & $\begin{array}{l}\text { untuk } \\
\text { mengetahui } \\
\text { pengaruh jumlah } \\
\text { wisatawan } \\
\text { mancanagera } \\
\text {,lama tinggal, } \\
\text { dan kurs dollar } \\
\text { Amerika } \\
\text { terhadap } \\
\text { penerimaan } \\
\text { produk } \\
\text { nusantara } \\
\text { regional bruto }\end{array}$ & $\begin{array}{l}\text { Regresi } \\
\text { linier } \\
\text { berganda }\end{array}$ & $\begin{array}{l}\text { secara parsial jumlah wisatawan } \\
\text { manca negara, dan kurs dolar } \\
\text { Amerika berpengaruh nyata dan } \\
\text { positif terhadap penerimaan } \\
\text { Produk Nusantara Regional Bruto } \\
\text { industri pariwisata Kabupaten } \\
\text { Badung, sedangkan lama tinggal } \\
\text { berpengaruh tidak nyata } \\
\text { terhadap penerimaanProduk } \\
\text { Nusantara Regional Bruto industri } \\
\text { pariwisata Kabupaten Badung. } \\
\text { Secara simultan jumlah } \\
\text { wisatawan mancanegara, lama }\end{array}$ \\
\hline
\end{tabular}




\begin{tabular}{|c|c|c|c|c|}
\hline & $\begin{array}{l}\text { Badung Tahun } \\
1997-2010\end{array}$ & $\begin{array}{l}\text { industry } \\
\text { pariwisata } \\
\text { Kabupaten } \\
\text { Badung tahun } \\
\text { 1997-2010 }\end{array}$ & & $\begin{array}{l}\text { tinggal, dan kurs dolar Amerika } \\
\text { berpengaruh nyata terhdap } \\
\text { penerimaan Produk Nusantara } \\
\text { Regional Bruto industri pariwisata } \\
\text { Kabupaten Badung }\end{array}$ \\
\hline $\begin{array}{l}\text { Eka } \\
\text { Armoni } \\
\text { (2011) }\end{array}$ & $\begin{array}{l}\text { Pengaruh } \\
\text { Pendapatan } \\
\text { Per Kapita, } \\
\text { Nilai Tukar, } \\
\text { Dan } \\
\text { Keamanan } \\
\text { Terhadap } \\
\text { Jumlah } \\
\text { Kunjungan } \\
\text { Wisatawan } \\
\text { Korea Selatan } \\
\text { Ke Bali }\end{array}$ & $\begin{array}{l}\text { untuk } \\
\text { mengetahui } \\
\text { Pengaruh/hubun } \\
\text { gan antara } \\
\text { Pendapatan Per } \\
\text { Kapita, Nilai } \\
\text { Tukar, Dan } \\
\text { Keamanan } \\
\text { Terhadap Jumlah } \\
\text { Kunjungan } \\
\text { Wisatawan Korea } \\
\text { Selatan Ke Bali }\end{array}$ & $\begin{array}{l}\text { Regresi } \\
\text { linier } \\
\text { berganda }\end{array}$ & $\begin{array}{l}\text { variabel pendapatan perkapita } \\
\text { (income percapita) dan nilai tukar } \\
\text { berpengaruh signifikan terhadap } \\
\text { jumlah kunjungan wisatawan } \\
\text { korea ke bali sedangkan variabel } \\
\text { keamanan tidak berpengaruh } \\
\text { terhadap terhadap jumlah } \\
\text { kunjungan wisatawan korea ke } \\
\text { bali. }\end{array}$ \\
\hline
\end{tabular}

Sumber : diolah dari berbagai sumber penelitian

\section{Landasan Teori}

\section{Pariwisata}

\section{Definisi Pariwisata}

Menurut Undang-undang No. 10 Tahun 2009 tentang kepariwisataan,Pengertian pariwisata adalah berbagai macam kegiatan wisata dandidukung berbagai fasilitas serta layanan yang disediakan olehmasyarakat, pengusaha, pemerintah, dan pemerintah daerah.

Pengertian lain dari Pariwisata menyebutkan bahwa periwisata adalah suatu perjalanan yang dilakukan untuk sementara waktu, yang diselenggarakan dari suatu tempat lain, denganmaksud bukan untuk mencari nafkah di tempat yang dikunjungi, tetapi semata-matauntuk menikmati perjalanan hidup guna bertamasya dan berkreasi untukmemenuhi keinginan yang beraneka ragam (Yoeti,2006).

Sedangkan Marpaung

mendifinisikan pariwisata sebagai perpindahan sementara yang dilakukan manusia dengan tujuan keluar daripekerjaan-pekerjaan rutin, keluar dari tempat kediamannya.Aktivitas dilakukanselama mereka tinggal di tempat yang dituju dan fasilitas yang dibuat untukmemenuhi kebutuhan mereka.

Soekadijo (1997) mendifinisikan pariwisata sebagai segala kegiatandalam masyarakat yang berhubungan dengan wisatawan. Semuakegiatan pembangunan hotel, pemugaran cagar budaya, pembuatanpusat rekreasi, penyelenggaraan pekan pariwisata, penyediaanangkutan dan sebagainya semua itu dapat disebut kegiatan 
pariwisatasepanjang dengan kegiatankegiatan itu semua dapat diharapkan parawisatawan akan datang.

Menurut World Tourism Organization (WTO) pariwisata adalah kegiatan seseorang yangbepergian ke atau tinggal di suatu tempat di luar lingkungannya yangbiasa dalam waktu tidak lebih dari satu tahun secara terus menerus, untukkesenangan, bisnis ataupun tujuan lainnya.(Pitana, 2009)

\section{Jenis-Jenis Pariwisata}

Menurut Pendit (1999)pariwisata dibagi menjadi beberapa jenis, antara lain: pariwisata menjadi beberapa jenis yaitu :

a. Wisata Industri, Perjalanan yang dilakukan oleh rombongan pelajar atau mahasiswa, atau orang-orang awam ke suatu kompleks atau daerah perindustrian dimana terdapat pabrik-pabrik atau bengkel-bengkel besar dengan maksud tujuan untuk mengadakan peninjauan atau penelitian. Misalnya, rombongan pelajar yang mengunjungi industri tekstil.

b. Wisata Politik, Perjalanan yang dilakukan untuk mengunjungi atau mengambil bagian aktif dalam peristiwa kegiatan politik. Misalnya, ulang tahun 17 Agustus di Jakarta, Perayaan 10 Oktober di Moskow,

c. Penobatan Ratu Inggris, Perayaan Kemerdekaan, Kongres ataukonvensi politik yang disertai dengan darmawisata.

d. Wisata Konvensi, Perjalanan yang dilakukan untuk melakukan konvensi atau konferensi. Misalnya APEC, KTT non Blok.

e. Wisata Sosial, Merupakan pengorganisasian suatu perjalanan murah serta mudah untuk memberi kesempatan kepada golongan masyarakat ekonomi lemah untuk mengadakan perjalanan seperti kaum buruh, pemuda, pelajar atau mahasiswa, petani dan sebagainya.

f. Wisata Pertanian, Merupakan pengorganisasian perjalanan yang dilakukan ke proyek-proyek pertanian, perkebunan, ladang pembibitan dan sebagainya dimana wisatawan rombongan dapat mengadakan kunjungan dan peninjauan untuk tujuan studi maupun melihat-lihat keliling sambil menikmati segarnya tanaman beraneka ragam warna dan suburnya pembibitan di tempat yang dikunjunginya. 
g. Wisata Budaya, Merupakan perjalanan wisata atas dasar keinginan untuk memperluas pandangan seseorang dengan mengadakan kunjungan atau peninjauan ke tempat lain atau ke luar negeri, mempelajari keadaan rakyat, kebiasaan dan adat istiadat mereka.

h. Wisata Kesehatan, Hal ini dimaksudkan dengan perjalanan seorang wisatawan dengan tujuan untuk menukar keadaan dan lingkungan tempat sehari-hari di mana ia tinggal demi kepentingan beristirahat baginya dalam arti jasmani dan rohani dengan mengunjungi tempat peristirahatan seperti mata air panas mengandung mineral yang dapat menyembuhkan, tempat yang memiliki iklim udara menyehatkan atau tempat yang memiliki fasilitas-fasilitas kesehatan lainnya.

i. Wisata Olah Raga, Wisatawan yang melakukan perjalanan dengan tujuan berolahraga atau. memang sengaja bermaksud mengambil bagian aktif dalam peserta olahraga disuatu tempat atau Negara seperti Asian Games,
Olympiade, Thomas Cup, Uber Cup dan lain-lain. Bisa saja olah raga memancing, berburu, berenang.

j. Wisata Komersial, Dalam jenis ini termasuk perjalanan untuk mengunjungi pameran-pameran dan pekan raya yang bersifat komersial, seperti pameran industri, pameran dagang dan sebagainya.

k. Wisata Maritim (Marina) atau Bahari, Wisata yang dikaitkan dengan kegiatan olah raga di air, lebih-lebih danau, bengawan, teluk atau laut. Seperti memancing, berlayar, menyelam, berselancar, balapan mendayung dan lainnya.

I. Wisata Cagar Alam, Wisata ini biasanya diselenggarakan oleh agen atau biro perjalanan yang mengkhususkan usaha-usaha dengan jalan mengatur wisata ke tempat atau daerah cagar alam, tanaman lindung, hutan daerah pegunungan dan sebagainya.

m. Wisata Buru, Wisata untuk buru, ditempat atau hutan yang telah ditetapkan pemerintah Negara yang bersangkutan sebagai daerah perburuan, seperti di Baluran, Jawa Timur untuk menembak babi hutan atau banteng. 
n. Wisata Pilgrim, Jenis wisata ini dikaitkan dengan agama, sejarah, adat-istiadat dan kepercayaan umat atau kelompok dalam masyarakat Ini banyak dilakukan oleh rombongan atau perorangan ketempat-tempat suci, ke makammakam orang besar, bukit atau gunung yang dianggap keramat, tempat pemakaman tokoh atau pimpinan yang dianggap legenda. Contoh makam Bung Karno di Blitar, Makam Wali Songo, tempat ibadah seperti di Candi Borobudur, Pura Besakih di Bali, Sendang Sono di Jawa Tengah dan sebagainya.

o. Wisata Bulan Madu, Suatu penyelenggaraan perjalanan bagi pasangan-pasangan, pengantin baru, yang sedang berbulan madu dengan fasilitasfasilitas khusus dan tersendiri demi kenikmatan perjalanan dankunjungan mereka.

\section{Pendekatan Pariwisata}

Terdapat empat pendekatan-pendekatan dalam pariwisata antara lain yaitu, (Spillane (1994) :

a. PendekatanAdaptancy, Pendekatan ini menyebutkan agar pengaruh negatif pariwisata dapat dikontrol dengan mencari bentuk lain perkembangan pariwisata dari yang selama ini sudah dikenal secara umum, atau dengan menyesuaikan pariwisata dengan Negara atau daerah tujuan wisata. Cara berpikir baru ini berdasarkan pandangan bahwa alam dan budaya dapat digabungkan dalam satu konteks.

b. Pendekatan Developmental, Pendekatan Developmental atau sering disebut pendekatan Alternative ini menganggap bahwa pariwisata dapat disesuaikan dengan keadaan masyarakat tuan rumah dan peka akan selera masyarakat tuan rumah tersebut Dapat dipercaya bahwa perkembangan tersebut sebetulnya mempengaruhi pilihan wisatawan terhadap daerah tujuan wisatanya dan demikian juga kehidupan mereka didaerah tujuan wisata atau bentuk alternative pariwisata ini mempengaruhi jurang pemisah antara hak dan kewajiban dari tamu, tuan rumah dan perantaranya.

c. Pendekatan Advocasy, Pendekatan ini mendukung pariwisata dan menekankan keuntungan ekonomis dari pariwisata. Potensi pariwisata bisa dipakai untuk 
mendukung macam-macam

kegiatan ekonomis, menciptakan lapangan kerja baru, memperoleh devisa asing yang dibutuhkan bagi pembangunan dan masih banyak lagi.

d. Pendekatan Cautionary, Pendekatan ini menekankan bahwa pariwisata banyak mengakibatkan banyak kerugian (disbenefits) dalam berbagai aspek sosial-ekonomi: seperti menimbulkan lapangan kerja musiman dan kasar (rendahan), mengakibatkan kebocoran devisa asing, menyebabkan komersialisasi budaya, serta menyebabkan berbagai macam konflik.

\section{Tempat Wisata}

\section{Definisi Tempat Wisata}

Yoeti (1997) mendifinisikan tempat wisata sebagai berbagai macam hal yang dapat dilihat, disaksikan, dilakukan atau dirasakan. Sedangkan Suwantoro (1997) mendifinisikan tempat wisata sebagai potensi yang menjadi pendorong kehadiran wisatawan kesuatu daerah, dan tempat wisata dibagi menjadi :

1. Obyek wisata dan daya tarik wisata alam, dimana obyek wisata ini memiliki daya tarik yang bersumber dari keindahan dan kekayaan alam.
2. Obyek wisata dan daya tarik budaya, dimana obyek dan daya tarik wisata ini bersumber dari kebudayaan, seperti peninggalan sejarah, museum, atraksi kesenian, dan obyek lain yang berkaitan dengan budaya.

3. Obyek wisata dan daya tarik pada minat khusus, dimana daya tarik dari obyek wisata ini bersumber dari minat khusus wisatawan itu sendiri, seperti olah raga, memancing dan sebagainya. Faktor Pendorong dan Penarik Pariwisata Goodal dalam Sharpley (1994), faktor pendorong merupakan faktor internal dalam diri individu (wisatawan)yang mempengaruhi yaitu kebutuhan dan keinginan seseorang yang memotivasi wisatawan untuk melakukan perjalanan wisata, sedangkan faktor penarik yang sesungguhnya merupakan faktor eksternal yang memotivasi wisatawan untuk mengadakan perjalanan wisata kesuatu daerah/tempat wisata.

\section{Hubungan antara jumlah kunjungan wisatawan dengan variabel-variabel yang mempengaruhinya dalam penelitian}

a. Tingkat Inflasi, inflasi diartikan sebagai kenaikan harga barang pada periode waktu tertentu, keinginan wisatawan untuk berkunjung kesuatu tempat atau kesuatu daerah (tempat wisata) tertentu akan dipengaruhi oleh harga- 
harga (naik atau turunya harga)

biasanya diukur dengan tingkat inflasi.

Wisatawan akan memiliki motivasi yang tinggi untuk mengunjungi tempat wisata ketika harga-harga turun atau stabil dan sebaliknya jika harga-harga naik (tinggi) atau terjadi inflasi maka motivasi/keinginan wisatawan untuk mengunjungi tempat wisata akan turun, sehingga inflasi akan mempengaruhi jumlah kunjungan wisatawan.

b. Kurs Valuta Asing, kurs valuta asing merupakan ukuran mata uang yang satu dengan mata uang lainnya yaitu ukuran antara dollar Amerika terhadap rupiah. Banyak atau sedikitnya kunjungan wisatawan akan dipengaruhi oleh nilai kurs dollar amerika terhadap mata uang rupiah, bagi wisatawan mancanegara kunjungan mereka kesuatu daerah wisata biasanya membawa dollar amerika untuk keperluan transaksi karena dollar amerika merupakan mata uang kuat (hard currency) yang biasanya digunakan untuk teransaksi di setiap Negara, ketika nilai mata uang dollar amerika turun terhadap mata uang nusantara (rupiah) atau nilai mata uang rupiah naik terhadap dollar amerika maka wisatawan asing akan mengeluarkan dollar lebih banyak dibandingkan ketika mata uang dollar naik nilainya terhadap mata uang nusantara (rupiah) untuk setiap transaksinya sehingga akan mempengaruhi keinginan (motivasi) wisatawan mancanegara untuk berkunjung ke suatu daerah wisata.

c. Nilai Produk NusantaraRegional Bruto (PDRB),merupakan ukuran pendapatan masyarakat suatu daerah/kabupaten/provinsi, dimana ketika pendapatan masyarakat (provinsi/kabupaten) meningkat maka keinginan untuk mengunjungi daerah wisatawan juga tinggi dan sebaliknya ketika pendapatan masyarakat (provinsi/kabupaten) turun maka keinginan untuk mengunjungi daerah wisatawan juga akan menurun sehingga besar atau kecilnya nilai PDRB maka akan mempengaruhi jumlah kunjungan wisatawan untuk berkunjung kesuatu tempat wisata

\section{METODE PENELITIAN}

\section{Jenis Penelitian}

Jenis penelitian yang digunakan dalam penelitian ini adalah penelitian eksplanatif yaitu penelitian yang bertujuan untuk mengetahui hubungan antara dua variabel atau lebih. Dengan penelitian ini 
maka akan dapat dibangun suatu teori yang dapat menjelaskan, dan meramalkan suatu gejala suatu variabel.

Penentuan lokasi penelitian dilakukan secara purposive sampling yaitu menentukan lokasi penelitian secara sengaja, lokasi penelitian adalah Kabupaten Lombok Utara (KLU)

\section{Jenis dan Sumber Data}

\section{Jenis data}

Jenis data dalam penelitian ini adalah :

a. Data kuantitatif yaitu data yang diperlukan dalam penelitian yang berupa angka angka yang dapat diukur besarnya dan dapat dihitung secara pasti seperti data PDRB, nilai tukar dan sebagainya

b. Data kualitatif yaitu data yang diperlukan dalam penelitian ini berupa keterangan dan kebijakan yang berkaitan dengan pengembangan pariwisata di kabupaten Lombok utara (KLU)

\section{Sumber data}

Data yang digunakan dalam penelitian ini adalah data sekunder, yaitu data yang pengguna tidak mengambil langsung dari responden/tempat penelitian tetapi sudah dalam bentuk data jadi yang tersedia pada instansi atau lembaga pengumpul data seperti BPS, bank Indonesia, dan instansi lainnya penyedia data lainnya dengan data pengamatan dari tahun 2012-2017.

\section{Metode dan Teknik pengumpulan data}

Metode pengumpulan data yang digunakan dalam penelitian ini adalah metode studi kasus, dimana peneliti ingin mengetahui variable-variabel yang menentukan jumlah kunjungan wisatawan di kabupaten Lombok utara (KLU)

Teknik yang digunakan dalam mengumpulkan data dalam penelitian ini adalah sebagai berikut:

a. Dokumentasi yaitu pengumpulan data berupa catatan-catatan yang tersedia pada lembaga terkait

b. Study kepustakaan, yaitu pengumpulan data dengan cara penelahaan kepustakaan dengan obyek- obyek yang akan dibahas dan bahan bacaan yang berhubungan dengan masalah yang diteliti.

\section{Identifikasi dan Klasifikasi Variabel}

\section{Identifikasi Variabel}

Variabel-variabel yang digunakan dalam penelitian ini adalah :

a. Kunjungan wisatawan Nusantara dan asing sebelum gempa bumi, satuan yang digunakan adalah (orang)

b. Kunjungan wisatawan Nusantara dan asing sebelum gempa bumi, 
satuan yang digunakan adalah (orang)

c. Tingkat Inflasi KLU, satuan yang digunakan adalah persentase (\%)

d. Kurs Valuta Asing, satuan yang digunakan adalah rupiah ( $R p)$

e. Nilai Produk Nusantara Regional Bruto (PDRB) KLU, satuan yang digunakan adalah rupiah ( $\mathrm{Rp})$

\section{Klasifikasi Variabel}

Variabel yang digunakan dalam penelitian ini diklasifikasikan menjadi :

a. Variabel Dependen/Variabel Terikat (Y), merupakan variabel yang dipengaruhi oleh variabel lain (variabel independen/bebas). Dalam penelitian ini variabel yang menjadi variabel dependen adalah jumlah kunjungan wisatawan nusantara dan Wisatawan asing sebelum dan setelah gempa bumi.

b. Variabel Independen/Variabel bebas $(X)$, merupakan variabel yang mempengaruhi variabel variabel dependen/terikat. Dalam penelitian ini variabel yang menjadi variabel independen adalah tingkat inflasi KLU (X1), tingkat kurs (X2), nilai PDRB KLU (X3).

\section{Definisi operasional variabel}

a. Kunjungan wisatawan. Variabel jumlah kunjungan wisatawan yang digunakan dalam penelitian ini menggunakan data banyaknya jumlah kunjungan wisatawan nusantara (dalam negeri) dan Mancanegara sebelum dan setelah gempa bumi dengan satuan (orang)

b. Tingkat Inflasi regional KLU. Inflasi regional merupakan kenaikan harga barang secara terusmenerus di tingkat local/regional, Inflasi yang digunakan dalam penelitian ini menggunakan inflasi KLU tahuhan dengan satuan yang digunakan adalah persentase (\%).

c. Kurs Valuta Asing, Kurs merupakan tingkat ukuran mata uang yang satu dengan mata uang lainnya yaitu ukuran antara rupiah dan dollar Amerika, satuan yang digunakan adalah rupiah (Rp)

d. Nilai Produk Nusantara Regional Bruto (PDRB) KLU. variabel ini merupakan produk yang dihasilkan oleh masyarakat suatu daerah (provinsi/kabupaten) dalam perekonomiannya, dimana PDRB juga menjadi ukuran pendapatan masyarakat di dalam suatu daerah (provinsi/kabupaten), satuan yang 
198 M.Mujahid Dakwah, Himawan Sutanto / Anafisis Diskriminan Kunjungan Wisatawan ...

digunakan untuk PDRB adalah rupiah $(\mathrm{Rp})$.

\section{Teknik Analisis Data}

Analisis yang digunakan dalam penelitian ini adalah analisis diskriminan, dimana Analisis diskriminan merupakan teknik statistik untuk mengklasifikasikan individu atau tempat ke dalam grup terpisah berdasarkan sejumlah variabel bebas. Tujuan utamanya adalah menemukan kombinasi linier dari sejumlah variabel bebas yang meminimalkan probabilitas salah klasifikasi individu atau tempat ke dalam masing-masing grup (Kuncoro, 2003: 222). Alat analisis yang digunakan adalah analisis Diskriminan, Multiple Discriminant Analysis (MDA). Analisis diskriminan merupakan teknik statistik untuk mengklasifikasikan individu atau tempat ke dalam grup terpisah berdasarkan sejumlah variabel bebas.

Tujuan dari penggunaan analisis diskriminan (Santoso, 2004 :219) antara lain.

1. Mencari nilai beda antara kelompok yang disebabkan oleh variabel diskriminator.

2. Mencari variabel diskriminantor yang paling dominan pengaruhnya dalam kelompok.

Penilaian tingkat signifikansi dari analisis diskriminan jika nilai (Wulder, 2002:4)

1. Eigenvalue lebih besar dari 1
2. Persentase dari varian lebih besar dari $5 \%$

3. Persentase kumulatif mendekati $75 \%$

4. Nilai Canonical correlation lebih besar dari 0.6

5. Semakin kecil nilai Wilk,s lambda, semakin tinggi $F$ rasio dan $P$ value yang signifikan yang menggambarkan pentingnya variabel yang di analisis.

Fungsi diskriminan yang digunakan adalah Fungsi diskriminan yang digunakan adalah $Z=\alpha_{0}+W_{1} X_{1}+W_{2} X_{2}+W_{3} X_{3}+\ldots . .+W_{n} X_{n}$ $Z=$ Discriminant score $\alpha_{0}=$ Konstanta

$W_{n}=$ Discriminant weight for independent variabel $n$

$\mathrm{X}_{1}, \ldots . . \mathrm{Xn}=$ Variabel Independen

Fungsi diskriminan ini di aplikasikan untuk menguji peranan sejumlah prediktor dalam membedakan sekaligus mempengaruhi wisatawan nusantara dan wisatawan mancanegara berkunjung ke tempat wisata di KLU. Prediktor yang digunakan adalah variabel Inflasi nasional, inflasi NTB, Kurs rupiah terhadap dollar, PDB, PDRB

\section{HASIL DAN PEMBAHASAN}

\section{Analisis Hasil Penelitian}

\section{Test of Equality of Group Means,}

tes ini digunakan untuk menilai tingkat signifikansi variabel yang terpilih, yaitu variabel yang memiliki nilai sig. $<5 \%$. 
Grafik 2 Tests of Equality of Group Means

Tests of Equality of Group Means

\begin{tabular}{|l|r|r|r|r|r|}
\hline & $\begin{array}{c}\text { Wilks' } \\
\text { Lambda }\end{array}$ & \multicolumn{1}{c|}{$\mathrm{F}$} & \multicolumn{1}{c|}{$\mathrm{df1}$} & \multicolumn{1}{c|}{$\mathrm{df2}$} & \multicolumn{1}{c|}{ Sig. } \\
\hline inflasi & .640 & 19.101 & 1 & 34 & .000 \\
PDRB & .372 & 57.448 & 1 & 34 & .000 \\
KURS & .271 & 91.256 & 1 & 34 & .000 \\
\hline
\end{tabular}

Nilai Wilk Lambda yang semakin mendekati 1 menunjukkan bahwa terdapat perbedaan antar variable Sebelum dan setelah terjadinya gempa bumi di kabupaten Lombok utara (KLU) Variabel yang berpengaruh signifikan dari Nilai Wilk Lambda diatas adalah variable Inflasi, PDRB dan variable Kurs karena nilai sig. $<\alpha=5 \%$

Tabel 2 Uji signifikansi

\begin{tabular}{|l|l|l|l|}
\hline Variabel & $\begin{array}{l}\boldsymbol{\alpha}=\mathbf{5 \%} \\
\mathbf{( 0 , 0 5 )}\end{array}$ & Sig. & Keterangan \\
\hline INFLASI & 0,05 & 0,000 & Signifikan \\
\hline PDRB & 0,05 & 0,001 & Signifikan \\
\hline KURS & 0,05 & 0,001 & Signifikan \\
\hline
\end{tabular}

\section{Variables in the analysis}

Grafik 3 Wilks Lambda

Wilks' Lambda
\begin{tabular}{|c|r|r|r|c|}
\hline TestofFunction(s) & $\begin{array}{c}\text { Wilks' } \\
\text { Lambda }\end{array}$ & Chi-square & \multicolumn{1}{c|}{ df } & Sig. \\
\hline 1 & .158 & 60.005 & 3 & .000 \\
\hline
\end{tabular}

Variabel yang dapat digunakan sebagai analisis dan Proses ini memperlihatkan tahapan setiap variabel yang dipilih. Grafik 4 variables in the analysis
Variables in the Analysis

\begin{tabular}{|c|c|c|c|c|}
\hline \multicolumn{2}{|c|}{ Step } & Tolerance & $\mathrm{F}$ to Remove & $\begin{array}{c}\text { Wilks' } \\
\text { Lambda }\end{array}$ \\
\hline 1 & KURS & 1.000 & 91.256 & \\
\hline \multirow[t]{2}{*}{2} & KURS & .999 & 34.802 & .372 \\
\hline & PDRB & .999 & 16.502 & .271 \\
\hline \multirow[t]{3}{*}{3} & KURS & .498 & 35.588 & .333 \\
\hline & PDRB & .938 & 19.025 & .252 \\
\hline & inflasi & .487 & 4.691 & .181 \\
\hline
\end{tabular}

Pada gambar diatas terlihat bahwa pada tahap ketiga proses ini berhenti untuk menghasilkan tiga buah variabel terpilih yaitu variabel kurs, PDRB dan Inflasi.

\section{Nilai Eigenvalue}

Nilai Eigenvalues ini bermanfaat untuk mengetahui berapa persen varian dari variabel $x$ yang berperan sebagai grouping variabel yang dapat dijelaskan oleh model diskriminan yang terbentuk.

Grafik 5 Eigenvalues

Eigenvalues

\begin{tabular}{|c|r|r|r|r|}
\hline Function & Eigenvalue & \% of Variance & Cumulative \% & $\begin{array}{r}\text { Canonical } \\
\text { Correlation }\end{array}$ \\
\hline 1 & $5.336^{\mathrm{a}}$ & 100.0 & 100.0 & .918 \\
\hline
\end{tabular}

a. First 1 canonical discriminant functions were used in the analysis.

Berdasarkan hasil output diatas diperoleh angka Eigenvalues pada fungsi 1 sebesar 5,336 dan angka Canonical Correlation sebesar 0,918. Artinya 91,8 \% varian dari variabel yang ada mempengaruhi kunjungan wisatawan sebelum dan setelah gempa bumi di kabupaten Lombok utara (KLU) dijelaskan oleh model diskriminan yang terbentuk, sisanya sebesar $8,2 \%$ dijelaskan oleh variabel lain/faktor lain. 
3. Wilks,s Lambda

Grafik 6 Wilks,s Lambda

Wilks' Lambda

\begin{tabular}{|c|r|r|r|r|}
\hline Testoffunction(s) & \multicolumn{1}{|c|}{$\begin{array}{c}\text { Wilks' } \\
\text { Lambda }\end{array}$} & Chi-square & \multicolumn{1}{c|}{ df } & \multicolumn{1}{c|}{ Sig. } \\
\hline 1 & .158 & 60.005 & 3 & .000 \\
\hline
\end{tabular}

Dari gambar diatas terlihat nilai ChiSquare hitung sebesar 60,005 dengan tingkat signifikansi 0,000 . Artinya bahwa ada perbedaan yang signifikan antara dua kelompok pada model diskriminan.

\section{Strukture Matrix}

Struktur matrix ini menjelaskan korelasi antara variabel independen dengan fungsi diskriminan yang terbetuk

Grafik 7 Strukture Matrix

\begin{tabular}{|c|r|}
\multicolumn{2}{c}{ Structure Matrix } \\
\hline & \multicolumn{1}{c|}{ Function } \\
\cline { 2 - 2 } & 1 \\
\hline KURS & -.709 \\
PDRB & .563 \\
inflasi & -.324 \\
\hline
\end{tabular}

Pooled withingroups

correlations

between

discriminating

variables and

standardized

canonical

discriminant

functions

Variables

ordered by

absolute size of

correlation

within function.

Dari gambar diatas terlihat variabel yang memiliki hubungan yang kuat antara variabel independen dengan fungsi diskriminan yang terbetuk adalah variabel kurs dengan nilai korelasi sebesar 0,70 (mendekati 1).

\section{Clasification Function Coefficients}

Calsification Function Coefficients ini berguna untuk mendiskriminasikan atau mengklasifikasikan sesuai dengan kelompok yang diamati.

Grafik 8 Classification Function

\section{Coefficients}

Classification Function Coefficients

\begin{tabular}{|l|c|c|}
\hline \multirow{2}{*}{} & \multicolumn{2}{|c|}{ Kunj wst } \\
\cline { 2 - 3 } & $\begin{array}{c}\text { kunjungan } \\
\text { setelah } \\
\text { gempa }\end{array}$ & $\begin{array}{c}\text { kunjungan } \\
\text { sebelum } \\
\text { gempa }\end{array}$ \\
\hline inflasi & -1991.869 & -1937.078 \\
PDRB & 22.164 & 30.512 \\
KURS & 1.837 & 1.782 \\
(Constant) & -7908.566 & -7534.904 \\
\hline
\end{tabular}

Fisher's linear discriminant functions

Berikut ini merupakan fungsi diskriminan linier kunjungan wisatawan seblum dan setelah gempa bumi di kabupaten Lombok utara (KLU) adalah sebagai berikut ;

Fungsi diskriminan pertama, $Z=-7908,56+1,837$ Inflasi $+22,16$ PDRB1991,86Kurs

Fungsi diskriminan kedua, $Z=-7534,90+1,782$ Inflasi+30,51PDRB1937,07 Kurs

\subsection{Pembahasan}

Dari analisis data diatas fakor-faktor atau variable yang membedakan kunjungan wisatawan yang berkunjung ke daerah wisata di kabupaten Lombok utara (KLU) sebelum dan setelah gempa bumi adalah semua variable yang digunakan yaitu 
variable kurs, PDRB dan inflasi yang dilihat dari Nilai Wilk Lambda yang semakin mendekati 1 menunjukkan bahwa terdapat perbedaan antar variable Sebelum dan setelah terjadinya gempa bumi di kabupaten Lombok utara (KLU) dan nilai signifikan dari variabel yang berpengaruh signifikan dari Nilai Wilk Lambda diatas adalah variable Inflasi, PDRB dan variable Kurs karena nilai sig. $<\alpha$ $=5 \%$.

Dari analisis data diatas juga terlihat bahwa ada perbedaan yang signifikan antara dua kelompok pada model diskriminan analisis kunjungan wisatawan sebelum dan setelah gempa bumi di kabupaten Lombok utara (KLU) yang terlihat dari nilai Chi-Square hitung sebesar 60,005 dengan tingkat signifikansi 0,000 .

Varian dari variabel inflasi, PDRB dan kurs yang berperan sebagai grouping variabel yang dapat dijelaskan oleh model diskriminan yang terbentuk pada kunjungan wisatawan sebelum dan setelah gempa bumi di kabupaten Lombok utara (KLU) yang terlihat dari nilai Eigenvalues pada fungsi 1 sebesar 5,336 dan angka Canonical Correlation sebesar 0,918 . Artinya $91,8 \%$ varian dari variabel yang ada mempengaruhi kunjungan wisatawan sebelum dan setelah gempa bumi di kabupaten Lombok utara (KLU) dijelaskan oleh model diskriminan yang terbentuk, sisanya sebesar $8,2 \%$ dijelaskan oleh variabel lain/faktor lain. Model diskriminan yang terbentuk dari dari kunjungan wisatawan sebelum dan setelah gempa bumi di kabupaten Lombok utara (KLU) adalah sebagai berikut ;

Fungsi diskriminan pertama, $Z=-7908,56+1,837$ Inflasi $+22,16$ PDRB1991,86 Kurs

Artinya kunjungan wisatawan sebelum gempa bumi di kabupaten Lombok utara (KLU) dipengaruhi oleh variable inflasi sebesar 1,8\%, variable PDRB sebesar 22,16\% dan variable kurs sebesar Rp 1991 Fungsi diskriminan kedua, $Z=-7534,90+1,782$ Inflasi+30,51PDRB1937,07 Kurs

Artinya kunjungan wisatawan setelah gempa bumi di kabupaten Lombok utara (KLU) dipengaruhi oleh variable/faktor inflasi sebesar 1,78\%, variable PDRB sebesar $30,51 \%$ dan variable kurs sebesar Rp 1937,07

\section{KESIMPULAN DAN SARAN}

\section{Kesimpulan}

1. Fakor-faktor atau variabel yang membedakan kunjungan wisatawan yang berkunjung ke daerah wisata di kabupaten Lombok utara (KLU) 
sebelum dan setelah gempa bumi adalah semua variable yang digunakan yaitu variable kurs, PDRB dan inflasi yang dilihat dari Nilai Wilk Lambda yang semakin mendekati 1 menunjukkan bahwa terdapat perbedaan antar variable Sebelum dan setelah terjadinya gempa bumi di kabupaten Lombok utara (KLU) dan nilai signifikan dari variabel yang berpengaruh signifikan dari Nilai Wilk Lambda diatas adalah variable Inflasi, PDRB dan variable Kurs karena nilai sig. $<\alpha=5 \%$.

2. Model yang dibentuk dari fungsi diskriminan yang digunakan dalam model dimana model diskriminan pertama, yaitu kunjungan wisatawan sebelum gempa bumi di kabupaten Lombok utara (KLU) dipengaruhi oleh variable inflasi sebesar $1,8 \%$, variable PDRB sebesar $22,16 \%$ dan variable kurs sebesar Rp 1991 sedangkan model diskriminan kedua, yaitu kunjungan wisatawan setelah gempa bumi di kabupaten Lombok utara (KLU) dipengaruhi oleh variable/faktor inflasi sebesar $1,78 \%$, variable PDRB sebesar 30,51\% dan variable kurs sebesar Rp 1937,07

3. Pada model diskriminan juga terlihat bahwa ada perbedaan yang signifikan antara dua kelompok pada model diskriminan analisis kunjungan wisatawan sebelum dan setelah gempa bumi di kabupaten Lombok utara (KLU) yang terlihat dari nilai Chi-Square hitung sebesar 60,005 dengan tingkat signifikansi 0,000.

4. Varian dari variabel inflasi, PDRB dan kurs yang berperan sebagai grouping variabel yang dapat dijelaskan oleh model diskriminan yang terbentuk pada kunjungan wisatawan sebelum dan setelah gempa bumi di kabupaten Lombok utara (KLU) yang terlihat dari nilai Eigenvalues pada fungsi 1 sebesar 5,336 dan angka Canonical Correlation sebesar 0,918. Artinya $91,8 \%$ varian dari variabel yang ada mempengaruhi kunjungan wisatawan sebelum dan setelah gempa bumi di kabupaten Lombok utara (KLU) dijelaskan oleh model diskriminan yang terbentuk, sisanya sebesar $8,2 \%$ dijelaskan oleh variabel lain/faktor lain.

\section{Saran}

1. Penelitian terhadap factor-faktor yang menentukan kunjungan wisatawan sebelum dan setelah gempa bumi di Kabupaten Lombok Utara (KLU) masih sangat kurang sehingga diperlukan 
adanya penambahan variabel di dalam penelitian ini bagi peneliti selanjutnya, agar aspek-aspek lain di dalam variabel yang paling mempengaruhi jumlah kunjungan wisatawan sebelum dan setelah gempa bumi di Kabupaten Lombok Utara (KLU) yang belum tercantum dalam penelitian ini agar dimasukkan sebagai variabel penelitian untuk menghasilkan penelitian yang lebih komprehensip.
2. Bagi pemerintah Pusat juga harus benar-benar menjaga stabilitas perekonomian nasional yaitu Inflasi, PDRB dan kurs secara local maupun nasional, karena akan menentukan besarnya biaya yang akan dikeluarkan oleh masyarakat yang ingin berwisata khususnya ke daerah wisata di kabupaten Lombok utara (KLU)

\section{DAFTAR PUSTAKA}

Anonin.Undang-Undang No. 10 Tahun 2009 Tentang Kepariwisataan

Ali Ibrahim, Mohammed.The Determinants of International Tourism Demand for Egypt: Panel Data Evidence.European Journal of Economics, Finance and Administrative Sciences ISSN 1450-2275 Issue 30 (2011)

Eka Armoni, Ni Luh. Pengaruh Pendapatan Per Kapita, Nilai Tukar, Dan Keamanan Terhadap Jumlah Kunjungan Wisatawan Korea Selatan Ke Bali. Jurnal Perhotelan dan Pariwisata, Agustus 2011, Vol.1 No.1 hal.2

Emilia Gabroveanu et,al. Analysis of Main Economic Factors Influence on Romanian Tourists Number Accommodated in Romania, using Anova Method.Theoretical and Applied Economics Journal 2010

Kuncoro,Mudrajad.2003. Metode Riset Untuk Ekonomi dan Bisnis.Erlangga.Jakarta Ghozali.2006.Analisis Multivariate Lanjutan Dengan ProgramSPSS. Badan Penerbit UNDIP. Semarang

Marpaung, Happy. 2002. Pengetahuan Kepariwisataan. Alpabeta Bandung.

Pendit, Nyoman. 1999. Ilmu Pariwisata Sebuah Pengantar Perdana. PT.Pradnya Paramita.Jakarta 
|104 M.Mujahid Dakwah, Himawan Sutanto / Analisis Diskriminan Kunjungan Wisatawan ...

Raymond Y.C. Tse. Estimating the impact of economic factorson tourism: evidence from Hong Kong.Tourism Economics Journal, 2001, 7 (3), 277-293

Sharifi \& Gilaninia.Economic Factors Affecting Tourism Supply.International Journal of Business and Behavioral Sciences Vol. 3, No.10; October 2013

Wijaya,I Nengah.Pengaruh Jumlah Wisatawan Mancanagera, Lama Tinggal, Dan Kurs Dollar Amerika Terhadap Penerimaan Produk Nusantara Regional Bruto Industry Pariwisata Kabupaten Badung Tahun 1997-2010.Tesis Pascasarjana Universitas Udayana 2011 